\title{
Reflections on the Nation-State in Western Europe Today
}

\section{Citation}

Hoffman, Stanley. 1982. Reflections on the Nation-State in Western Europe Today. Journal of Common Market Studies 21 (1): 21-38.

\section{Published Version}

http://dx.doi.org/10.1111/j.1468-5965.1982.tb00637.x

\section{Permanent link}

http://nrs.harvard.edu/urn-3:HUL.InstRepos:2624671

\section{Terms of Use}

This article was downloaded from Harvard University's DASH repository, and is made available under the terms and conditions applicable to Other Posted Material, as set forth at http:// nrs.harvard.edu/urn-3:HUL.InstRepos:dash.current.terms-of-use\#LAA

\section{Share Your Story}

The Harvard community has made this article openly available.

Please share how this access benefits you. Submit a story.

Accessibility 


\title{
Reflections on the Nation-State in Western Europe Today *
}

\author{
STANLEY HOFFMANN
}

Gone are the days when the champions and the theorists of European integration either called for or predicted the gradual transier of powers from the nation-state to a new European entity, either through a voluntary abdication of sovereignty, or through the subtle interplay of functional processes and economic interdependence. Today's reality is complex and messy. The nation-state has survived as the centre of political power and the focus of the citizens' allegiance; nationality remains the basis of citizenship, the main countervailing force that resists all the dissolvents of community. However, the nation-state coexists with a European enterprise that has limited but real powers, and considerable resilience. Indeed, the relations between the Community and its members are not a zero sum game; the Community helps preserve the nation-states far more than it forces them to wither away, and in recent years both the Community and its members have been battered by the economic storms. The notes which follow are meant, on the one hand, to examine the developments of the $70 \mathrm{~s}$, and on the other to raise a few questions of political theory.

\section{STATE AND SOGIETY REVISITED}

\section{Data}

The most striking reality is not the frequent and well-noted impotence of the so-called sovereign state. It is its survival, despite the turmoil. In Western Europe, the nation-state has withstood the massive removal of political confidence, the challenge to the social order of "consumer capitalism" and the "desacralization" of the state, manifest in France in 1968, and to a lesser extent in Italy and in some sectors of West Germany. It has also withstood the economic troubles of the 1970s: inflation and recession; an increase in unemployment that exceeds by far what had been deemed

*An earlier version of this paper was presented to the conference of "Europeanists" in Washington, DC in October 1980. 
politically tolerable; the plight of important traditional industries; the fragmentation of the labour markets and the development of dual economies; the advent of the era of "zero sum societies" marked by acute conflict among social groups for the distribution of a national product whose growth had slowed down or vanished; the dilemmas of governments caught between expansionist policies potentially disastrous for price stability and for the balance of payments, and restrictive policies with divisive internal effects; a general crisis of the welfare institutions caused by rising costs, and by the rigidifying effects of social protection and bureaucratic regulation on the national economy. The nation-state has also survived the insidious or perverse effects of economic interdependence, which entail a loss of control by the state over various essential instruments of policy - especially credit and monetary policy - because of the unintended consequences of attempts at using these instruments (i.e., attempts at raising interest rates in order to fight inflation, which attract vast amounts of foreign capital into the country; attempts at restricting access to foreign multinational enterprises, which incite them to settle in another member of the Community, etc....) and also because of the capricious role of uncontrolled forces - public or private external actors - on which no state has a grip.

This does not mean that the nation-state has carried out its economic, social and cultural functions successfully. But what has occurred has been complex. A number of predicted disasters have failed to take place. The end of deference, caused by changes in values as well as in social organization, has not led to the collapse of the educational systems, of professorial as well as of professional authority, which François Bourricaud seemed to expect: a legitimacy based on traditional obedience (or awe) has been replaced by a legitimacy based on functional competence. The Catholic Church has shown an extraordinary ability to adapt; here again, traditional obedience based on dogma has faded, and been replaced by a new legitimacy made of "reasoned faith" and widely recognized services to the polity. The challenge of "new forces": regional separatisms, the ecologists, the women's movements, all of which questioned the established practices of the nation-states, has been contained. The collapse of what Claus Offe has called "competitive party democracy"' has been avoided. There have been vast shifts among parties, but no "decline of the party system as the dominant force of mass participation". Theories of ungovernability have come in many forms; some have focused on the governments' overload resulting from rising social demands, others have stressed the effects which collapsing social controls, proliferating social interactions, and the communications explosion have had on the political sphere. But in

\footnotetext{
'François Bourricand, "Individualistic mobilization and the crisis of professional authority", Daedalus, Spring 1979, pp. 1-20.

${ }^{2}$ Claus Offe, "Competitive party democracy and the Keynesian welfare state", unpublished paper July 1981
} 
reality, there has been, instead, a fragmentation and even a lowering of public expectations and (as shown by the decline of the French Communist Party and of the CGT) a conspicuous absence of socio-political upheavals despite the frustrations of unions and other pressure groups.

While no West European government has succeeded in overcoming what is quite clearly a major and protracted capitalist crisis, three features stand out. The first is the ability of governments with a narrow popular majority to impose extensive sacrifices even on that part of the electorate that voted for the opposition, without major political dramas. The second feature is a greater ability of all West European governments on the one hand to experiment and to muddle through than in the 1930s (the rates of popular participation have been high, the fate of extremist parties has been sad) and on the other hand to maintain a higher level of social protection than in the United States despite the crisis of the welfare state. Thirdly, and paradoxically, in most instances, the reaction of the public and of the political elites to the partial impotence of the governments, to the constraints of economic interdependence, or to those imposed by dependence on the health and moves of the dominant economy: that of the United States, has been to cling to and if possible to re-enforce the nation-state. Growing opposition to the Community in England, a certain revival of German national feelings (if only in the form of a desire not to be a pawn of the super-powers), the French turn to a quite distinctive neo-Keynesian approach that is highly voluntaristic (by contrast with the Giscard-Barre approach), Italy's own closing of ranks under the threat of terrorism, are all manifestations of a national "sursaut".

As before, each nation-state of Western Europe has reacted in its own way. Not only does each one have its own profile, consisting in a peculiar configuration of economic data (rates of inflation, unemployment and growth, balance of payments, etc ...), but each one has faced the crisis according to its own political culture. For instance the contrast continues between a German approach marked by the memory of 1923 inflation (and what it did to Weimar) and a French collective phobia of unemployment and tolerance for inflation (Giscard lost largely because his priorities were the other way around). Each country has tried to fashion its own economic policies by combining and manipulating available instruments on behalf of national objectives (i.e., through national strategies involving the management of money and the rate of exchange, the budget, tax, social security, industrial and agricultural policies, energy policies etc ...). And each one has displayed its own political constellations, rooted in national political factors.

Thus, one can, with equal justification, talk about a relative bankruptcy of the nation-state, in so far as efficiency is concerned: the economic data speak for themselves; and talk about a double resilience of the nation-state, in so far as each one has survived, and done so in its own distinctive way. 


\section{Theories}

This resilience invites us to re-examine our theories, in two different realms: normative philosophical theories, and empirical sociological ones.

We still think in terms of the classical philosophical model of the liberal polity. As I have argued elsewhere, ${ }^{3}$ it "was based on three assumptions which have turned out untenable": emancipation of the individual, transparence (i.e., the society as a sum of individuals), and a limited state, either presiding over or marginally contributing to social harmony.

Reality does not correspond to this model. Individual emancipation has been thwarted by the recurrent crises of capitalist economies as well as by the permanent huge concentration of private and public power in capitalist-cum-welfare societies, by the social limits to growth which block individual satisfactions (cf. Fred Hirsch's analysis of positional goods, and of the role of collective bargaining), ${ }^{4}$ and by the effects of external events the international state of war. Hence, in much of the modern literature from the Marxists to Dahl and Lindblom - and indictment of the market, whose inequities stunt the development of the individual, and an analysis of the way in which both capitalism and the welfare institutions aimed at correcting it have given birth not to a fulfilled but to a fragmented person, not to a citizen but to a highly selfish and particularistic individual. Instead of transparence, we find the destruction of civility by the struggle for limited goods, and the opacity of groups which are frequently hierarchical and authoritarian (especially public bureaucracies), or oligarchic, conflictual and closed. As for the state, instead of reflecting society, it has become a separate social system, both victimized and bloated. It is victimized by the need to respect the laws of capital accumulation, the dynamics of capitalism, the constraints of international economic and strategic relations; by the logic of individual acquisitiveness, the drive of the "citizens" toward individualized calculations and benefits (which often undermines or thwarts policies of redistribution, and therefore social harmony); by the disproportion between costly attempts at correcting social inequities, and meagre public resources. And the state is bloated by the growth of a quasi-professional, representative elite for whom politics is a career rather than a service, by the growth of a bureaucracy often impervious to external control, and by the enormous extension of its own scope.

A reconstruction of the political theory of the modern polity is thus needed. It has barely begun, and it is difficult. Many of the alternatives to the (obsolete) liberal model are non-democratic. Attempts to conceptualize a democratic one have been plagued by three factors. First, there is excessive abstraction - a flaw that affects the most ambitious effort, John Rawls'

\footnotetext{
${ }^{3}$ Stanley Hoffmann, "Some notes on democratic theory and practice", Tocqueville Reviewe, Vol. II no. I, Winter 1980, pp. 59-76

${ }^{4}$ Fred Hirsch, The Social Limits to Growth, Harvard University Press, 1976, pp. $170 \mathrm{ff}$.
} 
Theory of Justice. Secondly, the very resilience of the contemporary nationstate, despite the obsolescence of the liberal model and the crisis of the welfare or social democratic one, creates a sense that the best one can do is describe, explain, rationalize and deplore that Strindbergian couple, the modern state and the truncated individual - a kind of normative abdication. Thirdly, attempts at offering a new normative theory at a tolerable level of abstraction often suffer from a kind of passéisme, a nostalgia for formulas rooted in the past.

This is the case of the neo-liberal (or neo-conservative) theory, which advocates reliance on the market yet somehow idealizes what Ronald Reagan calls its "magic" and conveniently forgets all the reasons that led to the attempts to correct its inequities - attempts whose own flaws or perverse effects are the only ills neo-conservatives observe. It is also the case of the auto-gestion utopia, which has the same aims (emancipation, transparence, harmony) as the liberal model, but fails to provide satisfactory answers to three important questions: how can what one French author has called an "auto-institutionalized society" reconcile territorial and professional self-management with indispensable central guidance? How can the community as a whole be protected against group selfishness, i.e., preserve the interests of the nation (and of outsiders), and the needs or claims of the future? Can the citizen increase his participation in all the groups, functions and roles in which he is involved, and if not, what is the best form of delegation?

A precondition for the reconstruction of political philosophy may well be a better understanding of contemporary society, i.e., a more sophisticated empirical sociological theory.

In turn, such a better understanding requires, as a first step, the discarding of the models that have dominated empirical theory in the $70 \mathrm{~s}-$ the various sociological models of industrial society. They have come in multiple forms. Suzanne Berger has distinguished its liberal from its marxist incarnations (they differ in their explanation of change and in their respective emphasis on cooperation vs. conflict ${ }^{6}$ Philippe Schmitter has listed three models of change (structural differentiation, historical materialism, political economy) ${ }^{7}$ But all offer what Suzanne Berger has called a "unitary theory of industrial society". It presents social integration as the product of the market, of increasing social mobility and mobilization. It stresses the central role of technology and, in James Caporaso's terms, "the expansion and rationalization of economic structures, the decline of

\footnotetext{
${ }^{5}$ Cornelius Castoriadis

${ }^{6}$ In: Suzanne Berger and Michael J. Piore, Dualism and Discontinuity in Industrial Societies, Cambridge University Press, 1980, pp. $132 \mathrm{ff}$.

${ }^{7}$ Philippe Schmitter, “On organizing interests", unpublished paper, 1979
} 
smaller, less efficient firms, the elimination of small agricultural holdings, ${ }^{8}$ all leading to higher growth.

These theories are misleading, because they are reductionist in three ways. They reduce social phenomena to mere effects of economic factors; thus, they discount the autonomy of politics, they deny the specificity of other sources of cleavage (ideological, ethnic, religious, linguistic, etc . . .). They are based on a theory of change which (like many theories of political development) is quasi-teleological, leaving no room for either the undetermined dialectic of groups within society, or the unpredictable impact of external events; thus they discount both the irreducible heterogeneity within each society and the discontinuities across borders, in other words the multi-directional nature of history; they focus on "industrial society" instead of the nation, on "society" rather than on the complex and conflictual agglomerations that make it up. And they reduce, in fact, the state to an epiphenomenon, produced by economic and social relations. Its autonomy is either denied (the state thus becoming a mere receptacle and by-product), or limited to whatever is functionally necessary to defend the social order (the state as guardian of the higher or long-term interest of the dominant class); or else the state is being reduced to a set of institutions somewhat decoupled from the rest of society, yet still analyzed primarily as the target or victim of social forces (the besieged state).

Here, unlike what we found in the realm of political philosophy, a reconstruction has begun. In order to understand both the resilience and the relative impotence of the nation-state, as well as the sharp differences between state performances, we need what I would call a state-centred, pluralistic and structured approach. It must be state-centred, because of the double autonomy of politics (the domain of social demands focused specifically on the state, thus becoming political issues) and of the state (constrained by these demands, dependent on support, yet endowed with a capacity to innovate and to act on its own). It must be pluralistic, because of the diversities within society and the state as well as among states and societies. It must be structured, because each nation has its own keys and dynamics, produced by history and by the configuration of economic interests, social forces and institutions. This approach would be less predictive and more analytic than the current prevailing one. It can be summarized in four propositions.

One: The famed distinction between state and society is a necessary point of departure because there is, in the modern nation, a functional differentiation between them which results from the monopoly of authoritative decisions and of public force enjoyed by the state. But it is a bad compass for analysis. For what is striking everywhere is the role of political

\footnotetext{
${ }^{8}$ James Caporaso, "The European Community in the world system", English version (May 1979) of a paper published in the Revue d'intégration européenne.
} 
parties as intermediaries between and agents of (both) the state and society; the increasing penetration of society by the state (as Philippe Schmitter has noted, "neo-corporatism" facilitates governability - at a cost); and the increasing public role played by large private organizations, whether or not they operate in a kind of symbiosis with the state bureaucracy or as partners in the majority coalition: witness the help the unions have often given to the state in the economic crisis of the recent past, either by presenting demands for a "structural" state policy that implicitly recognizes the necessity of industrial reconversion (as long as it is planned), or else by agreeing to limit wage demands in exchange for progress on other issues (for instance a reduction of the length of work or an improvement in working conditions) or in exchange for the maintenance of social benefits.

Two: The nation-state is a social system in which the state, positively or negatively, plays a decisive role. I would propose distinguishing three notions. One is the autonomy of the state, which concerns the influences and pressures of society on the state, and has three dimensions: the capacity to resist particular pressures (including those that emanate from the majority parties or from fragments of the bureaucracy), the resulting capacity of the state to produce its own ideas and goals, and the capacity to turn its preferences into decisions ( $\mathrm{cf}$. the remarkable study by Eric Nordlinger).$^{9}$ A second notion is the strength of the state, which consists both of its capacity to be autonomous and of its internal capacity to act; the latter, in turn, depends on two factors: the organization of the state and the balance between its scope and its resources. The third notion is the effectiveness of the state, i.e., the ability to achieve results by influencing society, which of course depends on its autonomy and strength, but can, even in the case of a strong and autonomous state, be crippled by internal obstacles (for instance, excessive centralization) or by externally (i.e., social) resistances caused by a multiplicity of factors: technical or political mistakes made by the government, inequalities and extended privileges, opposition to change, etc. ... We need to focus on the ways in which, more or less autonomously, more or less strongly, more or less efficiently, the state acts, not merely as a mediator between internal demands and external pressures, but as a shaper capable of moulding its own domestic support, of choosing among internal interests and external constraints, of playing some against others, of using the fragmentation of interests and classes in order to fashion - to preserve or to reform - the social order, of using the challenges of complexity, the expansion of its scope, and the imperatives and constraints of the international system in order to define the common interest. It is this ability to appear not as a receptacle, or a prisoner of its base, but as a creator, as a dampener or a solver of conflicts, which is the key to its effectiveness. Whatever the official ideology, in every post-war

\footnotetext{
${ }^{9}$ Eric Nordtinger, On the Autonomy of the Democratic State, Harvard University Press, 1981.
} 
West European nation, the state has been granted an overall responsibility for and by society. Being the focus of expectations, it can easily be a source of disappointment; but it also has two paradoxical assets: it can attenuate (as Crozier has shown) ${ }^{10}$ the crisis of social control that affects European societies, or deprive it of political expression; and it helps preserve the political parties as forces that resist the universal privatization of concerns and counteract group fragmentation. Thus - not in the old legalistic way, but in a more sociological perspective that looks at the constant interactions with society - we must again examine closely the state's own structures and institutions, which make it more or less capable of playing its creative role.

Three: Each nation-state proceeds in its own way. As Peter Katzenstein's work has shown, ${ }^{11}$ the main variables are the following ones. Some are structure and process variables: the degree of centralization of the state, the configuration of central political power (the constitutional system especially concerning the issue of Executive autonomy - and the party system), the degree of centralization of the main interest groups, the degree of state penetration into society (which entails an analysis of the main policy instruments), the nature of the relations between the state and the principal interests (who leads whom, who deals with whom?), the relationship to the outside world (degrees of openness, of sensitivity and of vulnerability). Also, there are ideological variables: the visions of the main actors, as well as their historical memories. And finally, their main policies must be examined.

Four: Despite the creative role of the state, all the nation-states of Western Europe have a narrow range of manoeuvre. Whatever the momentary national economic policy, all have a high vulnerability to inflation, largely because of external constraints (dependence on exports, energy imports, a common commitment to an open international economy). All have to be deeply concerned with industrial restructuring - an imperative for internal economic growth and external competitiveness. None can afford to compress wages and social benefits, à l'américaine, because of the risks of social explosions. On the one hand, the combination of a narrow margin of choice with the lynchpin role of the state, or of huge state scope and limited resources, or of strength and ineffectiveness, produces new lines of cleavage and tensions in society. On the other hand, paradoxically, the narrow margin of choice re-enforces the system: the voters tend to behave pragmatically, with a firm grasp of the "reality principle", and extremist parties have only the choice between staying in a ghetto (cf. the French CP before 1981 and perhaps British Labour) and acting with

\footnotetext{
${ }^{10}$ In M. Crozier, Samuel P. Huntington and Joji Wanatuki, The Crisis of Democracy, New York University Press 1975, pp. $39 \mathrm{ff}$.

"See especially Peter Katzenstein "Problem or model: West Germany in the 80's", World Politics, July 1980 , pp. 577-598.
} 
moderation (cf. the Italian CP). This resilience is partly caused by the very factors which the sociological theories of industrial society overlook or deem dysfunctional: external ones, such as the European Community (see below), or the cushioning role of migrant workers, on whom the burden of adjustment can be pushed; internal ones, such as the reservoir provided, in periods of economic crisis, by the so-called declining classes, or the fragmentation of issues and groups, i.e., the social discontinuities and heterogeneity which make possible the kinds of bargains that either push economic difficulties away from the centre to the periphery ( $\mathrm{cf}$. the role of the regions in Italy) or divert public attention from economic difficulties (cf. the appeal of "law and order", used by conservative governments to keep the support of economically threatened groups).

\section{THE NATION-STATE VERSUS THE COMMUNITY}

\section{Theories}

After the remarkable explosion of theories about integration in the $1950 \mathrm{~s}$ and early $60 \mathrm{~s}$, we find a sudden drought.

The grand theory which had been, implicitly, Jean Monnet's and, explicitly, Ernst Haas', has performed much better as an initial goad than as a permanent explanation. Derived from the theories of industrial society, it suffered from the same weaknesses. It relied on technology as the fuel, and on the logic of the market as the motor of integration: the drive for economic modernization would lead to political unity. It was the old Saint-Simonian dream of depoliticized progress, accompanied by one idea that, at first sight, seemed on the contrary quite political: the idea that the gradual dispossession of the nation-state and the transfer of allegiance to the new Community would be hastened by the establishment of a central quasi-federal political system (however, it was conceived as largely bureaucratic in nature).

What this theory neglected was, in the first place, the difference between two kinds of politics. I have, in the past, called them "high" versus "low", but this can be misleading if it suggests that foreign policy and defence are always and exclusively "high", which is not the case, and economic and social policies are "low", which is certainly false, especially in periods of economic crisis. I would prefer to distinguish the politics which aims at or allows for the maximization of the common good, from the politics of either do ut des (strict reciprocity) or of the zero-sum game. Whether an issue falls into one or the other category depends on its momentary saliency - on how essential it appears to the government for the survival of the nation or for its own survival, as well as on the specific features of the issue (some do not lend themselves to "maximization of the common good" or to "upgrading the common interest"), and on the economic conjuncture. At any rate, the 
politics of reciprocity and of the zero-sum game re-enforce the existing states.

The theory also overlooked the differential impact, on the various nations, of external countries (such as the two superpowers). Moreover it underestimated the ability of the actors, especially the major ones, to stop or to slow down the building of a central political system (the role of counter-ideas, if you like) and the ability of national bureaucracies to resist the transfer of power to the new central one (the power of inertia). It would be of little use to replace the Monnet-Haas theory with a "world systems" approach borrowed from Wallerstein. The world system may be a useful concept for economic theory. For a historian or political scientist, it is a majestic fiction. ${ }^{12}$ The world economic system is not a prime mover, nor a God-like distributor of roles and divider of labour, but the outcome of discrete political decisions made by the separate units. These, as usual, are constrained by the effects of their own moves: they are submitted to common forces, often beyond their own control; but they are not governed by these forces; once more we find here the error of teleology, and the teleology of technology. Indeed, in the case of the West European entity, the whole question is whether Europe's place in the "world system", i.e. in the international division of labour, will be defined by the nation-states' separate decisions, or by the EEC.

The way of moving toward a new theory should be the following. We must begin with the units themselves; what are their domestic priorities and the foreign policy goals of the member states, to what extent are they compatible, and can they best be fostered by cooperation? Then we should examine the impact of the environment on the separate actors. Finally we would study the institutional interplay between the states and the Community's organs.

\section{Recent trends}

The history of the EEC in the past ten years shows some persistent realities. At the level of the units, we find, first, that the political life of each has remained dominated by the specific national configuration of the variables listed above, not by the constellation in Brussels. Secondly, each national bureaucracy has preserved its peculiar features, thus making effective common policies more difficult, given the different patterns of strengths and weaknesses of each bureaucrary, and the bureaucracies' different attitudes toward public regulation and control (cf. the history of the steel crisis, or of energy policy). Thirdly, different traditions and outlooks in foreign policy have continued. All these factors explain

\footnotetext{
${ }^{12}$ See the critique by Theda Skocpol, "Wallerstein's world capitalist system", American Journal of Sociology, March 1977, pp. 1075-90.
} 
Community failures or fiascoes in areas like transportation, industrial policy, fisheries, and employment.

At the level of the Community we find, on the one hand, common obstacles. In defence, there is both common dependence on the US and a lasting split between France and the states that remain in the military structure of NATO; also, much harm has been done to the Community by the "globalization" of issues within its jurisdiction - the fact that the half-continent is an inappropriate framework for dealing with energy, with North-South issues or with the Arab - Israeli conflict. On the other hand, the old institutional morass has persisted: the "Federal" institutions have weak powers, and their main organs often paralyze one another; these troubles, in turn, have depressing effects on the other components of the emerging or expected "central" political system - community-wide interest groups or party alignments.

To these continuing elements, some new developments have been added. Several have been positive. If one compares the EEC today with the Community of $1974-5,{ }^{13}$ one finds a number of innovations. One is a limited but, so far, tenuously successful attempt at monetary cooperation, the EMS, based on a common interest of Bonn and Paris - Bonn's interest in a zone of monetary stability and in a scheme that would protect the Deutschmark from becoming too strong, Paris's interest in an external constraint on domestic inflationary pushes.

Equally positive has been the definite evolution and rapprochement of foreign policy objectives. Each of the major West European actors has tried to get "the best of all possible worlds" - Bonn has moved from total reliance on the US in defence and diplomacy (and on European integration for rehabilitation), to a partial liquidation of the specific German problems (Berlin and the iron curtain), which has allowed West Germany to develop its relations with Moscow and with Eastern Europe. France has moved from a multifaceted, almost maniacal search for independence from the US (under the American umbrella), to a combination of military autonomy plus co-operation with NATO, détente plus activism (in Africa and the Middle East), a national energy policy plus oil deals. London has moved from the "special relationship" and the Commonwealth to entry into the Common Market. As a result, two of the three major actors - West Germany and France - have developed strong links with Moscow, and all three, for reasons that are partly similar and partly different, have somewhat detached themselves from Washington. Indeed, the US has often played an involuntarily integrative role: by inflicting recurrent shocks on Bonn (cf. Carter's non-proliferation, "locomotive" and human rights policies), through the divagations of American economic and monetary policies

13 See my essay "No trumps, no luck, no will", in: James Chace and Eari Ravenal, Atlantis Lost, New York University Press 1976, pp. $1-46$. 
(which have fostered a European desire for protection against the fluctuations of the dollar, and now against America's high interest rates), because of the passivity of US policy in the Arab - Israeli conflict since Camp David, and because of Washington's insistence on the indivisibility hence the death - of détente ever since the invasion of Afghanistan. ${ }^{14}$

Other developments have been negative. First, the institutional crisis has got worse. The EEC's institutions are weak, because they lack autonomy (from the member states) and because their capacity to act is small. The European Council, designed as a kind of supreme command, has been counter-productive: it has decapitated the Council and compounded the problems of congestion and enforcement. The Council has declined, partly because of overspecialization. The Parliament, now elected by universal suffrage, has not vindicated either the nightmare of Michel Debré (who thought it would behave like the Third Estate's deputies in 1789) or the dream of the Federalists; it has simply and sumptuously displayed a rich array of cleavages (national, ideological, and along the lines of interests). Secondly, the enlargement of the Community has proven indigestible. It has worsened the language problem and weakened the cohesion of the Commission, hence adding to the institutional crisis. Britain has, almost every year, asked for special treatment and renegotiated its contribution to the budget. Greece is now acting in a similar way.

The Community's balance sheet is thus mixed. In internal (European) affairs, there has been more frequent resort to article 235 of the Treaty of Rome, which allows for an extension of scope, but there are - by comparison with the initial period of the 1950 s - no more common goals, only common concerns. Franco-German reconciliation has been achieved; the strong earlier impulse for innovation - away from the dismal past - has been replaced by an equally strong desire - on the part of the members and of the central Brussels bureaucracy as well - to preserve the status quo. Partly as a result, common policies are rare (and the oldest, the Common Agricultural Policy whose establishment helped strengthen the Community, has now become a source of Community weakness; it is in deep trouble because of different national performances, different national policies in agriculture, different national attitudes toward inflation, and the effect of monetary manipulations). There is, as the Committee of Three remarked in its October 1979 report, ${ }^{15}$ a disproportion between efforts and outcomes: a huge amount of political and administrative labour produces meagre results - recurrent deadlocks and minimal compromises. The original "project" - a gradual pooling of sovereignties - has in fact been sacrificed to the politics of enlargement: enlargement and what Maurice Schumann used to call "deepening" have turned out incompatible. And

\footnotetext{
${ }^{14}$ See my essay "The Western Alliance: drift or harmony", International Security, Fall, 1981, pp. 105-125.

${ }^{15}$ Report on European Institutions, Council of the European Communities, 1980.
} 
the economic crisis of recent years has affected the Community adversely in two ways: each government has sought, above all, national solutions - even when there was an air de famille among the economic policies of Schmidt, Thatcher and Barre, even more so after the election of Mitterrand; and Community efforts at devising common plans (for industrial reconversion, for instance) or at preserving common policies (agriculture) have been disrupted by protectionist moves and monetary manoeuvres.

In external affairs, however, the members have behaved increasingly as an entity. Within the EEC, there has been a display of activism on NorthSouth matters (Lomé II) and of solidarity with Britain in the Falkland Islands crisis (sanctions against Argentina); outside of the framework of the treaty of Rome, European political cooperation has progressed far beyond the first steps of the "Davignon procedure"; the Nine (or Ten) now define common stands without first consulting Washington. This has been partly caused by an institutional paradox (most of foreign policy coordination is not encumbered by the organs set up by the Treaty of Rome), partly the result of a fuite en avant - a compensation for internal paralysis, partly the product of estrangement from Washington. But the ratio of common acts versus common statements - deplorations and exhortations remains low, and some of the common acts (such as Lomé II) have a limited scope.

Western Europe? The best way of analyzing the EEC is not in the traditional terms of integration theory, which assumes that the members are engaged in the formation of a new, supranational political entity superseding the old nations - an outcome that was originally possible but has become increasingly more unlikely - and that there is a zero-sum game between the nation-states on one hand, the EEC on the other - a very false notion. It is to look at the EEC as an international regime, as defined by Keohane and Nye: ${ }^{16}$ a set of norms of behaviour and of rules and policies covering a broad range of issues, dealing both with procedures and with substance, and facilitating agreements among the members. From the viewpoint of the participants, such a regime provides both restraints and opportunities - it limits the state's freedom of unilateral action (for instance, here, in agriculture or in external trade) and it imposes financial loads (cf. Britain and West Germany), but it gets others to share one's burdens (cf. regional policy) or to accept restraints in one's favour (the GAP): i.e., it provides the participant with external support (hence the crucial importance of coalition-building, issue by issue, year after year).

The comparative study of international regimes shows that they are most likely to be established in areas where, and at moments when, "sovereign", national actions are likely to be insufficient or unproductive: when joint actions produce better results, for each member, than "uncoordinated

${ }^{16}$ R. O. Keohane and J. S. Nye, Power and Interdependence, Little Brown, 1977. 
individual calculations of self-interest", ${ }^{17}$ in areas of high "issue density", marked by interdependence and linkages among the issues. ${ }^{18}$ But the study also shows that regimes may be doomed to paralysis or failure when the balance of constraints and opportunities shifts in the direction of the former. The experience of the EEG confirms this. Its establishment resulted from the conviction of the members that purely national action in a variety of economic domains was no longer satisfactory, and that a number of major non-economic goals could best be achieved by setting up a collective regime. Its performance has conformed to the observation that regimes require a principle of long-term reciprocation (i.e., I refrain from maximizing my self-interest now in the hope and expectation that you will return the favour when $I$ need it in the future), ${ }^{19}$ and are able to survive changes in the original patterns of interests because of a shift in the criteria by which national decisions are made (i.e., from a more selfish to a more enlightened definition of the national interest) and because of the interest which the members develop in the institutions themselves. ${ }^{20}$ But the difficulties encountered by the EEC in handling the economic crisis of the $70 \mathrm{~s}$ and early 80 s results from the inability of the members to agree on common constraints (i.e., from the persistent differences in priorities and in monetary and fiscal policies) and from the inability of the central institutions to devise common opportunities to overcome a crisis largely caused by extra-European forces. As Miles Kahler has written, "national elites have chosen certainty of declining effectiveness over the perils of coordination with the same risks". ${ }^{21}$ It is not so much the distribution of power among the members which has changed, endangering the regime, as the relative attractiveness of individual versus common action at a time when the latter does not seem to promise better outcomes than the former.

However, for almost everyone of the members, the overall balance of restraints and opportunities remains acceptable: hence the resilience of the Community. The balance is different for each state, and it has evolved. In the case of West Germany, legitimation has become less important, yet economic and political benefits continue to assure Bonn's loyalty to Brussels. In the case of France, containing West Germany is no longer a dominant concern, but foreign policy influence, and the contribution the Community makes to the modernization of French industry and agriculture remains essential. For Italy, membership of the EEC has been important both for domestic politics and as a key factor in what might be called

\footnotetext{
${ }^{17}$ Stephen D. Krasner, "Structural causes and regime consequences", International Organization, Spring 1982, p. 191.

${ }^{18}$ Robert O. Keohane, "The demand for international regimes", Int. Org., Spring 1982, p. 339

${ }^{19}$ Keohane, ibid., p. 342, and Robert Jervis, "Security regimes", Int. Org., Spring 1982, p. 364.

${ }^{20}$ Arthur A. Steir, "Coordination and collaboration", Int. Org., Spring 1982, pp. 322-3.

${ }^{21}$ Miles Kahler, "The survival of the state in European international relations", unpublished paper, April 1981
} 
deparochializing Italy. The only partial exception is Britain, because of the costs imposed on a member that remains economically more turned toward non-EEC countries than the other members of the Community, and whose agricultural policy rests on very different principles. These costs exacerbate the fundamental and unresolved British contradiction between external burdens and domestic imperatives, a contradiction de Gaulle largely eliminated in France's case.

Far from being static, ${ }^{22}$ the notion of an international regime allows, indeed incites, the study of change: a regime can flourish or decay, it can degenerate into a mere façade behind which the rule of self-interest prevails, or tighten into a quasi-political community. Analyzing the EEC as an international regime allows one also to see better what, to "integrationists", is a paradox or a contradiction: such regimes, in exchange for curtailing the states' capacity for unilateral action, serve to preserve the nation-state as the basic unit in world affairs and actually help governments perform their domestic tasks. Athough the traditional model of sovereignty is clearly obsolete, the nation-state today survives even though some of its powers have to be pooled with others, and even though many apparently sovereign decisions are seriously constrained, or made ineffective by, the decisions of others as well as by economic trends uncontrolled by anyone. International regimes help the state survive, by providing a modicum of predictability and a variety of rewards.

We must go farther: the EEC regime is unique (it has central institutions and a common market), and it has served not only to preserve the nationstates, but paradoxically to regenerate them and to adapt them to the world of today. Far from leading to a supranational, European nationstate, it has put pressure on the members to modernize their economies: $\mathrm{cf}$. France and its agriculture, the UK and its industry, and the way in which the EEC's North-South policies and attempted opening to the imports from the New Industrial Countries (NIC) gradually incite the members to accept a new international division of labour. The EEC has also served as an alibi for governments too weak to take unpopular measures on their own, or strengthened their hand against protectionist or inflationary pressures (indeed, in the past, Britain and Italy have preferred to turn to the IMF for help, because the IMF's conditions were less constraining). And the Community has served as a playing field for "inter-issue bargaining", allowing for complex deals in which concessions in one realm were offset by gains in another. In all these ways, and despite its internal flaws, the EEC regime has strengthened the nation-state's capacity to act at home and abroad.

${ }^{22}$ Susan Strange, "Cave! Hic dragones", Int. Org., Spring 1982, pp. 488-91. 
Problems for the future

One major problem for the future of the EEC results from the differences in economic performance among the member states. Different rates of inflation, in the long run, threaten the survival of the EMS, or expose it to recurrent shocks, and increase protectionist pressures in countries that cannot easily devalue in order to compensate for the decreasing competitiveness of their exports. The difference between countries that try to mitigate the current economic crisis with "orthodox" policies, and France, which has launched an experiment in national action against unemployment through the extension of the public sector, may also result in a kind of creeping protectionism in France. Some of the members are more threatened than others, by the common predicament of European industry - the squeeze between the US and Japan on one hand, the NIC's on the other. Economic divergences thus risk undermining or fragmenting the EEC regime. When the states have weak governments, and ineffective and divergent policies, negative solidarity between the nation-state and the EEC operates: both suffer. When the governments are strong, and their policies are effective and convergent, the impact on the EEC is ambiguous.

In the $80 \mathrm{~s}$, the question mark of a common defence may become more salient, especially if tensions between the US and Western Europe increase. In defence, there is no European regime, but a multiplicity of regimes NATO integration (Bonn), a mix of independence and cooperation (Paris), a combination of the two (London). Now, the future presents a paradox. The capacity of each state to assure an independent defence will keep declining. This means a major change in the traditional cement of nationhood: the state's ability to provide security had been a major ingredient. (There are other ingredients, precisely because of the increasing role of the state in supplying economic and social services. But these new cements are more ambiguous: they tend to make the state less autonomous, and to be sources of contention more often than factors of national solidarity). Nevertheless, a common West European Defence regime would probably be very difficult to establish. It would not eliminate (even if it would partly alleviate) the fundamental plight: the need to rely on America's nuclear guarantee (and on an American conventional and nuclear presence, which gives credibility to this guarantee); this is a fact that is likely to be used by European opponents of a new EDC, and especially by all those who want to keep West German fingers as far away as possible from nuclear triggers, or who fear Bonn's preponderance in a conventional defence regime. Should the Americans withdraw their nuclear guarantee (except in case of a Soviet nuclear attack), ${ }^{23}$ the result is more likely to be increased fragmentation (i.e. French reliance on nuclear weapons, Bonn's on a mix of conven-

\footnotetext{
${ }^{23}$ See the article by McGeorge Bundy, George Kennan, Robert McNamara and Gerald Smith, "Nuclear weapons and the Atlantic Alliance", Foreign Affairs, Spring 1982, pp. 753-768.
} 
tional defence and détente) than a common West European security régime, given the obstacles to a pooling of nuclear efforts and the unwillingness to prepare for a conventional war, i.e., to abandon deterrence for defence.

Moreover, a common defence regime would be much more damaging for the nation-state than the economic and monetary regimes achieved so far. These have strengthened the nation-state more than they have dispossessed it. A defence Community would require a leap toward more powerful central institutions: here, the relation between Community and states is a zero-sum game. This is another reason why so little has been undertaken. But this vacuum, or absence, is a major source of weakness, both for each West European nation, and for the "civilian" European entity as a whole. 